\title{
The Influence of Salt Solutions and Soil Interspace on the Fungal Counts of Stored Tomatoes in Cooling Structures
}

\author{
Sunmonu Musliu Olushola
}

\begin{abstract}
A study was conducted to study the Influence of salt solution and soil interspace on the total fungal counts of stored tomatoes in Cooling Structures. Three sets of four different types of passive evaporative cooling structures made of clay and aluminium. One set consists of four separate cooling chambers. Two cooling chambers were made with aluminium container (cylindrical and rectangular shapes) and the other two were made of clay container (cylindrical and rectangular). These four containers were separately inserted inside a bigger clays pot and inter- spaced with clay soil of $5 \mathrm{~cm}$ with the outside structure wrapped with jute sack. The other two sets followed the same pattern with interspacing of $7 \mathrm{~cm}$ and $10 \mathrm{~cm}$ respectively. The set with $7 \mathrm{~cm}$ interspace served as the control in which the interspace soil and the jute sack were wetted with water at room temperature. The other two sets were wetted with table salt solution. The fungal counts on the stored tomatoes were determined at interval for a period of sixteen days. The effects of the fungal counts on the weight and nutritional values of the produce were determined using ANOVA. Further analysis by DNMRT was carried out to compare the means. The total fungal counts of 13.7, 13.6, 13.0, 11.8 and $10.8 \mathrm{ppm}$ were recorded for the tomatoes stored in 5 cm soil inter space while the total fungal counts of $13.7,13.8$, 12.7, 12.5 and $11.5 \mathrm{ppm}$ were recorded in $7 \mathrm{~cm}$ soil interspace.while $14.3,14.4,13.4,12.9$ and $12.1 \mathrm{ppm}$ were recorded in the $10 \mathrm{~cm}$ soil interspace.
\end{abstract}

Index Terms - Fungal count, interspace, soil, solution.

\section{INTRODUCTION}

The loss in the post-harvest period may originate from infections that were initiated by fungi during the growing season well in advance of harvest. Much of this pre-harvest infection involves a group of fungi that are capable of infecting healthy developing fruits either by direct penetration, e.g., anthracnose diseases caused by species of colletctrichum or by invasion via natural openings much as lenticels or stomates or through breaks in the tissue at the points of attachment of fruits to the plant. In many cases the infection process may be incomplete. Thus, sub-cuticular mycelium may be formed which remains in a latent stage until the post-harvest period when changes in susceptibility may occur and the pathogen mycelium may ramify through the tissue.

The freshness quality and consumer safety of fruits and vegetables depend on the microbial population at harvest, as well as during storage [1]. Fruit andvegetables are highly susceptible to microbial contamination during growth, harvest and postharvest operations [2]. Moulds classified as

Manuscript received September 24, 2014; revised January 12, 2015.

M. Sunmonu is with the University of Ilorin, Ilorin, PMB 1515 Nigeria (e-mail: sholams2000@yahoo.co.uk). fungi develop a multicellular structure visible to the naked eye. They grow from cells called spores present in the air and can attack leaves of plants. They settle and multiply on suitable foods. At this stage, they are visible as a fluffy coloured mass and the food is said to have gone mouldy. Moulds grow most readily in most conditions, at temperatures between $20^{\circ} \mathrm{C}$ and $40^{\circ} \mathrm{C}$. They grow on a variety of foods, particularly meat, cheese, fruit and bread, The most common pathogens causing rots in vegetables and fruits are Alternaria, Botrytis, Diplodia, Monilinia, Phomopsis, Rhizopus, Pencillium, Fusarium (caused by fungi) [3].

Late blight of tomato is caused by fungus phtophthora. The affected fruit develop brown to dark brown spots/lesions which may later engulf the entire fruit. Also white colony mycelia often develop on the fruit during wet conditions [4], [5]. Black mold is a ripe tomato fruit rot caused by fungus Alternaria alternate [6]. The disease on the ripe fruit is characterized by lesions ranging from small brown flocks to large black circular sunken areas [7]. Lesions cause major loss in texture until the fruit collapses. A. niger is a fungus commonly found on tomatoes [8]. Tomato is highly prone to the spoilage of fungi especially Aspergillusspecies, Penicilliumspecies and Trichodermaspecies [9]. Artificial infection studies showed that the fruits were susceptible to infection at all stages of ripeness [10]. Fusarium spp. was the most common fungi in citrus fruits [11]. Studies on the fungi associated with tomato rot showed seven fungi associated with fruit rot of tomato including Fusariumequiseti, A. flavus and $A$. niger, they were all pathogenic on tomato fruits [12]. A. flavus caused tomato spoilage were also investigated by [13]. Infection by fungi and bacteria mayoccur during the growing season, at harvest time, during handling, storage, transport and marketing, or even after purchase by the consumer [14] .

There is need to practically control all factors capable of adversely affecting the safety, nutritive value, appearance, texture, flavor, and keeping qualities of raw and processed foods. Since thousands of food products differing in physical, chemical, and biological properties can undergo deterioration from such diverse causes as microorganism ,natural food enzymes, insects and rodents, industrial contaminants, heat, cold, light, oxygen, moisture, dryness, and storage time, food preservation methods differ widely and are optimized for specific products.

The Copper fungicides have been used for the protection of many vegetables, fruits and flowering plants for many plant diseases. Copper sulfate is a naturally occurring inorganic salt, also known as basic Copper sulfate, blue stone and blue vitrol. It is used to control a variety of bacterial and fungal diseases of fruits, nuts, vegetables and field crops [15]. [16] have reported that heavy metals are generally toxic to microorganisms especially if these metals are present at high 
concentrations [17]-[19].

The basic principle of evaporative cooling relies on cooling by evaporation. When water evaporates it draws energy from its surrounding which produces a considerable cooling effect.

This paper focuses on the Influence of salt solution and soil interspace on the total fungal counts of stored tomatoes in Cooling Structures.

\section{MATERIALS AND METHODS}

The experiment was carried out in Minna, Niger state, Nigeria and the samples of tomatoes were sourced from Garatu Market. The fresh tomatoes were stored inside the three sets of four different types of passive evaporative cooling structures for a period of 16 days. 30 samples of fresh oranges were stored in each structure.

\section{A. Microbial Analysis}

The total fungal plate counts were determined using the methods of [20].

\section{B. Preparation of Salt Solution}

About 15000 parts/millions (ppm) solution of sodium chloride ( $\mathrm{Nacl}$ ) was prepared by dissolving $225 \mathrm{~g}$ of $\mathrm{Nacl}$ in 15 litres of water at room temperature and $450 \mathrm{~g}$ of $\mathrm{Nacl}$ in 30 litres of water at room temperature for keeping the four structures in moist condition in the $5 \mathrm{~cm}$ and $10 \mathrm{~cm}$ soil inter-space respectively. The four structures in the $7 \mathrm{~cm}$ soil inter space were kept in moist condition using 20 litres of water.

\section{RESUlTS AND DISCUSSION}

The result of this study based on the fungal analysis of stored tomatoes in each structure is as presented in table 1.From the table, it shows that higher values of total fungi counts were obtained in the $7 \mathrm{~cm}$ soil interspace structures compared with the tomatoes stored in the $5 \mathrm{~cm}$ soil interspace structures throughout the storage period due to the absence of salt solution as wetting media to control the growth of fungi.

This can be confirmed from plate 2 which represents the storage condition of stored tomatoes with $7 \mathrm{~cm}$ interspace when compared with the $5 \mathrm{~cm}$ and $10 \mathrm{~cm}$ soil interspace. The higher values of fungal counts in the $7 \mathrm{~cm}$ soil interspace are an indication of higher population of fungi on the stored tomatoes. The tomatoes in the tin-in-pot and pot-in-pot structures appears water soaked initially which later developed into a mycelia structure. The mycelia structure is a white fluffy hairlike covered with a thin cotton like fungal structure suspected to be Rhizopus rot.

Also the tomatoes in tin-in-wall and wall-in-wall structures developed dark brown sporulations that cover the cotton like white structure suspected to be ring rot (Myrotheciumroridum) [21], [22]. The affected tomatoes were removed immediately before they affect other fruits in storage. The result obtained in $5 \mathrm{~cm}$ soil interspace was as a result of the application of salts of sodium (Nacl) showing decrease in fungi growth may be due to toxic nature of these compound on cellular metabolism of the fungi as suggested by [23]. However, higher values of fungal counts were recorded in $10 \mathrm{~cm}$ soil interspace when compared with $5 \mathrm{~cm}$ and $7 \mathrm{~cm}$ soil interspace (Table I). This was as a result of soil cracking that allows rapid transportation of water to the subsoil [24]-[26]. This action of soil cracking give room for fungi to settle around the remaining part of the soil interspace not affected by cracking as greater percentage of salt solution must have found their ways into the cracks. Thus given rise to higher fungi population that later gained entrance into the storage structures. The $7 \mathrm{~cm}$ soil interspace allows uniform distribution of water into the soil without developing cracking; thus generating the necessary cooling effect needed for the high quality of stored tomatoes (see Fig. 1-Fig. 3).

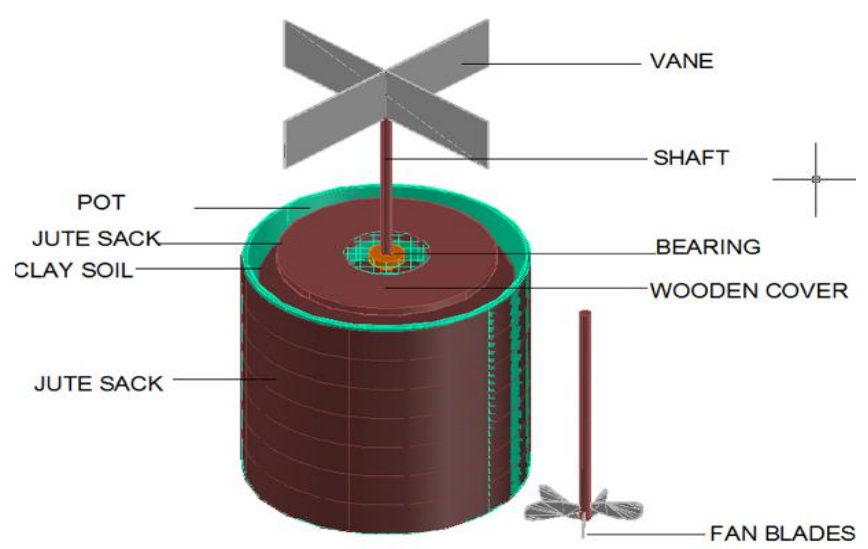

Fig. 1. Parts labelling of the cylindrical structure.

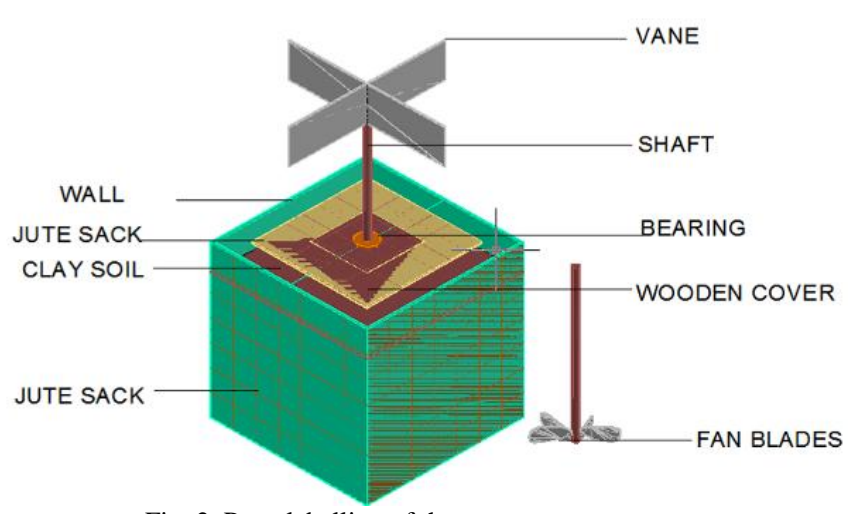

Fig. 2. Parts labelling of the square structure.
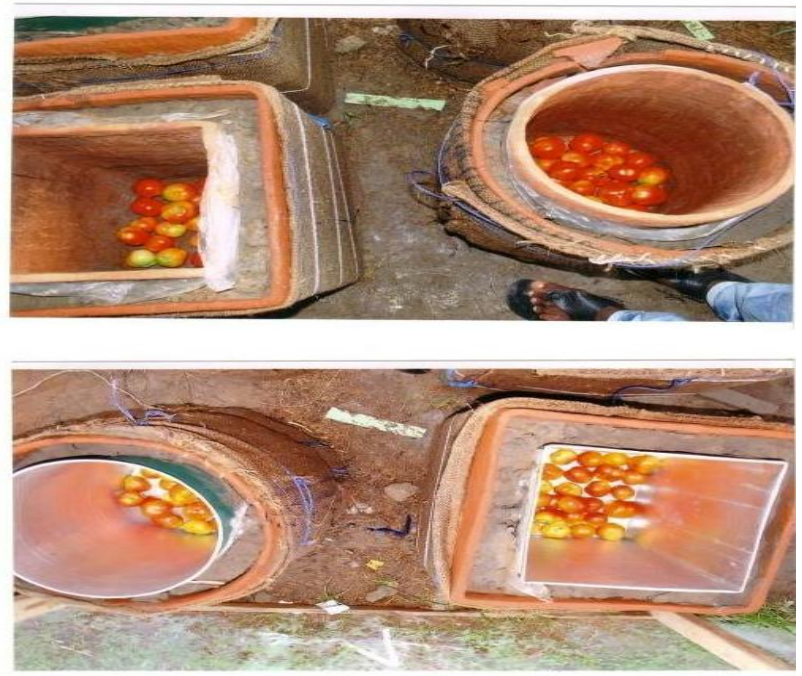

Fig. 3. The inside of the strorage structures.

The action of fungi activity is also more in stored tomatoes 
as it affects their weight, vitamin $\mathrm{E}$ and lycopene contents (see Table III). The stored tomatoes in cylindrical structures made with aluminium (with $7 \mathrm{~cm}$ and $10 \mathrm{~cm}$ soil interspace) gave better results by producing more of red color of stored tomatoes than produce in rectangular structures made with clay which is a $\mathrm{n}$ indication of higher lycopene contents [27].

Texture also determines the acceptability of fruits and vegetables and to evaluate the quality of stored produce. It is observed that produce stored in cylindrical structures made with aluminium gave better results in texture especially with $10 \mathrm{~cm}$ soil interspace. This may be attributed to the use of table salt (Nacl) as wetting media which reduced the population of microorganisms feeding on the epicarp of stored produce; thus maintaining the firmness of the produce by reducing postharvest decay and improving their qualities by controlling the development of physiological disorder [28], [23]. The result obtained in $5 \mathrm{~cm}$ soil interspace was as a result of the application of salts of sodium (Nacl) showing decrease in fungi growth may be due to toxic nature of these compound on cellular metabolism of the fungi as suggested by [23]. Also, results analysis of variance (ANOVA) in Table 3 revealed a significant difference in the fungal counts in the values of vitamin $\mathrm{E}$ and lycopene contents in stored tomatoes. This was as result of higher rate of ripening taking place in stored tomatoes which increase the activity of microorganisms especially in $5 \mathrm{~cm}$ soil interspace [29], [30].

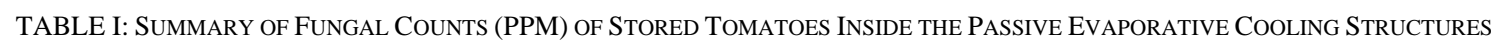

\begin{tabular}{|c|c|c|c|c|c|}
\hline \multicolumn{6}{|c|}{ Storage Storage Period (Days) } \\
\hline Structures & 1 & 5 & 9 & 13 & 16 \\
\hline \multicolumn{6}{|l|}{$5 \mathrm{~cm}$} \\
\hline Tin-in-pot & $3.8 \times 10$ & $3.8 \times 10$ & $3.2 \times 10$ & $3.4 \times 10$ & $2.8 \times 10$ \\
\hline Pot-in-pot & $2.9 \times 10$ & $3.1 \times 10$ & $3.2 \times 10$ & $2.6 \times 10$ & $3.0 \times 10$ \\
\hline Tin-in-wall & $3.4 \times 10$ & $3.6 \times 10$ & $3.2 \times 10$ & $3.0 \times 10$ & $2.8 \times 10$ \\
\hline Wall-in-wall & $3.6 \times 10$ & $3.1 \times 10$ & $3.4 \times 10$ & $2.8 \times 10$ & $2.2 \times 10$ \\
\hline Total & $13.7 \times 10$ & $13.6 \times 10$ & $13.0 \times 10$ & $11.8 \times 10$ & $10.8 \times 10$ \\
\hline \multicolumn{6}{|l|}{$7 \mathrm{~cm}$} \\
\hline Tin-in-pot & $3.6 \times 10$ & $3.8 \times 10$ & $3.3 \times 10$ & $3.6 \times 10$ & $2.6 \times 10$ \\
\hline Pot-in-pot & $3.0 \times 10$ & $3.0 \times 10$ & $3.0 \times 10$ & $2.8 \times 10$ & $2.8 \times 10$ \\
\hline Tin-in-wall & $3.9 \times 10$ & $3.6 \times 10$ & $3.2 \times 10$ & $3.1 \times 10$ & $3.0 \times 10$ \\
\hline Wall-in-wall & $3.2 \times 10$ & $3.4 \times 10$ & $3.2 \times 10$ & $3.0 \times 10$ & $3.1 \times 10$ \\
\hline Total & $13.7 \times 10$ & $13.8 \times 10$ & $12.7 \times 10$ & $12.5 \times 10$ & $11.5 \times 10$ \\
\hline \multicolumn{6}{|l|}{$10 \mathrm{~cm}$} \\
\hline Tin-in-pot & $3.8 \times 10$ & $3.8 \times 10$ & $3.2 \times 10$ & $3.8 \times 10$ & $2.8 \times 10$ \\
\hline Pot-in-pot & $3.6 \times 10$ & $3.6 \times 10$ & $3.2 \times 10$ & $3.0 \times 10$ & $3.2 \times 10$ \\
\hline Tin-in-wall & $3.8 \times 10$ & $3.4 \times 10$ & $3.6 \times 10$ & $3.2 \times 10$ & $2.8 \times 10$ \\
\hline Wall-in-wall & $3.1 \times 10$ & $3.6 \times 10$ & $3.4 \times 10$ & $2.9 \times 10$ & $3.2 \times 10$ \\
\hline Total & $14.3 \times 10$ & $14.4 \times 10$ & $13.4 \times 10$ & $12.9 \times 10$ & $12.1 \times 10$ \\
\hline
\end{tabular}

TABLE II: ANALYSIS OF VARIANCE ON THE EFFECT OF FUNGAL COUNTS ON NUTRITIONAL VALUES OF STORED TOMATOES

\begin{tabular}{|c|c|c|c|c|c|c|}
\hline & & Sum of Squares & Df & Mean Square & $\mathrm{F}$ & Sig. \\
\hline & Between Groups & 3.385 & 11 & .308 & .579 & $.836^{*}$ \\
\hline \multirow[t]{3}{*}{ VA } & Within Groups & 25.507 & 48 & .531 & & \\
\hline & Total & 28.893 & 59 & & & \\
\hline & Between Groups & 5.163 & 11 & .469 & 1.400 & $.204 *$ \\
\hline \multirow[t]{3}{*}{$\mathrm{VC}$} & Within Groups & 16.091 & 48 & .335 & & \\
\hline & Total & 21.254 & 59 & & & \\
\hline & Between Groups & 1.216 & 11 & .111 & 2.862 & $.006^{*}$ \\
\hline \multirow[t]{3}{*}{ VE } & Within Groups & 1.854 & 48 & .039 & & \\
\hline & Total & 3.069 & 59 & & & \\
\hline & Between Groups & .075 & 11 & .007 & 2.583 & $.012 *$ \\
\hline \multirow[t]{2}{*}{ LP } & Within Groups & .127 & 48 & .003 & & \\
\hline & Total & .202 & 59 & & & \\
\hline
\end{tabular}

WT=weight, VA=vitamin A, VC=vitamin C, VE=vitamin E, LP=lycopene, *significant at 5\% 


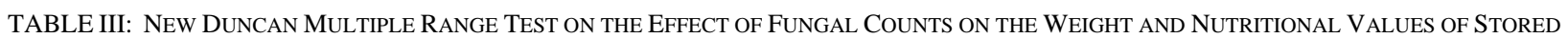
TOMATOES AT DiFFERENT STORAGE PARAMETERS

\begin{tabular}{ccc}
\hline Tomato & Soil Interspace & Weight \\
& $5 \mathrm{~cm}$ & $2.6472 \mathrm{E} 2 \mathrm{a}$ \\
& $7 \mathrm{~cm}$ & $2.7830 \mathrm{E} 2 \mathrm{a}$ \\
& $10 \mathrm{~cm}$ & $2.6899 \mathrm{E} 2 \mathrm{a}$ \\
\hline & & Weight \\
\hline Tomato & Storage Structure & $2.8737 \mathrm{E} 2 \mathrm{a}$ \\
& 1 & $2.5398 \mathrm{E} 2 \mathrm{~b}$ \\
\hline & 2 & Weight \\
\hline Tomato & Material & $2.7960 \mathrm{E} 2 \mathrm{a}$ \\
& 1 & $2.6174 \mathrm{E} 2 \mathrm{~b}$ \\
\hline Tomato & 2 & Vitamin E \\
\hline & Soil Interspace & $3.3050 \mathrm{a}$ \\
& $5 \mathrm{~cm}$ & $3.3000 \mathrm{a}$ \\
\hline & $7 \mathrm{~cm}$ & $3.3350 \mathrm{a}$ \\
\hline Tomato & $10 \mathrm{~cm}$ & Vitamin E \\
\hline & Storage Structure & $3.3467 \mathrm{a}$
\end{tabular}

\begin{tabular}{ccc}
\hline & & \\
\hline Tomato & Material & Vitamin E \\
\hline & 1 & $3.3800 \mathrm{a}$ \\
\end{tabular}

\begin{tabular}{ccc}
\hline Tomato & Soil Interspace & Lycopene \\
\hline & $5 \mathrm{~cm}$ & $1.3160 \mathrm{a}$ \\
& $7 \mathrm{~cm}$ & $1.3270 \mathrm{a}$ \\
& $10 \mathrm{~cm}$ & $1.3210 \mathrm{a}$ \\
\hline Tomato & Storage Structure & $1.3020 \mathrm{a}$ \\
\hline & 1 & $1.3407 \mathrm{~b}$ \\
\hline Tomato & 2 & Lycopene \\
\hline & Material & $1.3353 \mathrm{a}$ \\
\hline
\end{tabular}

M=Material Component for the Storage Structures (1represents tin component made of aluminium material while 2 represents pot /wall components made of clay material)Means with the same alphabet are not significantly different from each other.

SS= Storage Structures (1 represents tin-in-pot and pot-in-pot which are cylindrical in shape while 2 represents tin-in-wall \& wall-in-wall which are rectangular in shape)

*Means with the same alphabet are not significantly different from each other.

\section{CONCLUSION}

This paper focuses on the Influence of salt solution and soil interspace on the total fungal counts of stored tomatoes in Cooling Structures. It was observed that salt solution affects the growth of fungi on tomato fruits by drastically reducing their population. The results revealed higher values in weights and nutritional parameters in cylindrical structures when aluminium material was used. Also in comparison with the control, the results showed a significant reduction ( $\mathrm{p} \leq$ 0.05 ) in fungal counts in $5 \mathrm{~cm}$ and $10 \mathrm{~cm}$ soil interspace as a result of the salt solution. It is recommended that the wetting of the jute sack and soil interspace should be done with salt solution at $15000 \mathrm{ppm}$ instead of water at room temperature so as to reduce the growth of fungi on fruits.

\section{REFERENCES}

[1] R. E. Brackett, "Shelf stability and safety of fresh produce as influenced by sanitation and disinfection," Journal Food. Prot, vol. 55, no. 10, pp. 808-814, 1992.

[2] J. M. Madden, "Microbial pathogens in fresh produce-The regulatory perspective," Journal Food. Prot., vol. 55, pp. 821-823, 1992,

[3] K. T. Chandy, "Post-harvest loss of fruits and vegetables," Booklet, no. $74,2000$.
[4] P. A. Koepsell and J. W. Pscheidt, "Pacific northwest plant disease control handbook," Extention services of Oregon state university and the University of Idaho, 1994.

[5] A. A. Macnab and A. F. Sherf, Vegetable Diseases and Their Control, John Willey and Sons, Newyork, 1986.

[6] E. G. Simmons, Typification of alternariastemphyylium and ulocladiummycologia, vol. 59, pp. 67-92, 1967.

[7] R. C. Pearson and D. H. Hall, "Factors affecting the occurrence and severity of blacmold on ripe tomato fruit caused by alternariaalternata," Phytopathology, vol. 65, pp. 1352-1359, 1975.

[8] H. Yildz and T. Batsal, "Effects of alternative current heating treatment on aspergillusniger, pectinmethylesterase and pectin content in tomato," Journal Food Engineering, vol. 75, pp. 327-332, 2000.

[9] A. Ghosh, "Moulds in food spoilage," International Journal Food Microbial, vol. 33, no. 1, pp. 85-102, 2009.

[10] V. A. Palejwala, C. K. Patki, S. V. Bhatti, and V. V. Modi, "Postharvest spoilage of mangoes by aspergillusniger," International Journal Food Microbial, vol. 5, pp. 111-116, 1987.

[11] V. H. Tournas and E. Katsoudas, "Mould and yeast flora in fresh berries, grapes and citrus fruits," Int. Journal Food Microbial., vol. 105, pp. 11-17.

[12] A. O. Oladiran and I. N. Iwu, "Studies on the fungi associated with tomato fruit rots and effects of environment on storage," Mycopathol, vol. 121, pp. 157-161, 1993.

[13] V. A. Adisa, "Some extracellular enzymes associated with two tomato fruit spoilage molds," Mycopathologa, vol. 91, pp. 101- 108, 1992.

[14] C. Dennis, Postharvest Pathology of Fruits and Vegetables, Academic press, London, 1983.

[15] Y. L. Nene and P. N. Thapliyal, Plantdisese Control and Fungicides, $2^{\text {nd }}$ edition, 1996, pp. 15-24. 
[16] I. F. Hallos and J. J. Cooney, "In resistant microorganisms in Chesapeake bay," Appl. Environ. Microbiol, vol. 41, pp. 446-471, 1981.

[17] G. M. Gadd and A. J. Griffiths, "Microorganisms and heavy metal toxicity," Microbe Ecol., vol. 4, pp. 303-317, 1978.

[18] J. M. Wood and H. K. Wang, "Microbial resistance to heavy metals," Environ. Sci. Technol., vol. 17, pp. 582-590, 1985.

[19] H. L. Ehrlich, "Interaction of heavy metals and microorganism," Numeral Exploration: Biological Systems and Organic Matter, vol. 5 , pp. 22- 27, 1986.

[20] C. H. Collins, P. M. Lyne, J. M. Grange, and J. O. Falkinham, Collins and Lynes Microbiological Methods, Amold publishers $8^{\text {th }}$ edition, 2004.

[21] J. B. Jones, J. Jones, R. Stall, and T. Zitter, Compendium of Tomato Disease, APS press, St. Paul, MN, 1991.

[22] A. L. Snowdon, Color Atlas of Postharvest Diseases and Disorders of Fruits and Vegetables, CRC press, Boca Raton FL., vol. 2, 1992.

[23] C. J. Alexopoulos., C. W. Mims, and G. A. Strobel, Introductory Mycology, $4^{\text {th }}$ edition, NY Willey, 1996.

[24] D. E. Kissel, J. T. Ritchie, and E. Burnett, "Nitrate and chloride in heavy soil," Journal of Environmental Quality, vol. 3, no. 4, pp. 401-404, 1974

[25] G. L. Harris, P. H. Nicholls, S.W. Bailey, K. R. Howse, and D. J. Mason, "Factors influencing the loss of pesticides in drainage from cracking clay soil," Journal of Hydrology, vol. 159, pp. 235-263, 1994.
[26] J. J. B. Bronswijk, W. Hamiminga, and K. Oustindae, "Field scale solute transport in a heavy clay," Water Resources Research, vol. 31, pp. 517-526, 1995.

[27] D. K. Salunkhe and B. B. Desai, Postharvest Biotechnology of Vegetables, CRC press, inc, Boca Raton, Florida, 1984, pp. 55-82.

[28] L. Chiessa, L. Diaz, O. Cascone, K. Penak, S. Camperi, D. Frezzaa, and A. Fragaus, "Texture changes on normal and long shelf life of tomato," International Society for Horticultural Science, vol. 464, no. 1, 1998.

[29] S. J. Roura., L. A. Davidovich, and C. E. Valle, "Quality loss in minimally processed Swiss chard related to amount of damage areas," Lebensmittelwissenschafttechnol, vol. 33, pp. 53-59, 2000.

[30] A. E. Watada and D. A. Minott, "Factors affecting quality of fresh-cut horticultural products," Postharvest Biology Technology, pp. 115-125, 1996.

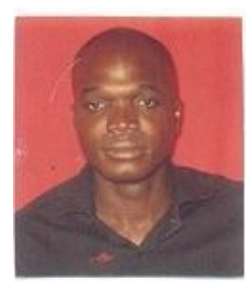

M. O. Sunmonu is currently working at the Department of Agricultural and Bios stems Engineering, University of Ilorin.

His research interests are in the area of design and development of post-harvest technologies and modeling of post-harvest systems.

Dr. Sunmonu also won a scholarship to attend International Training Programme at Practical Training Centre, Oenkerk, Neatherlands in 2010 fully sponsored by the Dutch government and he was issued a certificate for attending the international training programme on milk processing. 